\title{
Effects of Elevated Temperatures on the Compressive Strength Capacity of Concrete Cylinders Confined with FRP Sheets: An Experimental Investigation
}

\author{
Sherif El-Gamal, Khalifa Al-Jabri, Ahmed Al-Mahri, and Saud Al-Mahrouqi \\ Civil Engineering Department, Sultan Qaboos University, Al-Khodh, P.O. Box 33, 123 Muscat, Oman \\ Correspondence should be addressed to Sherif El-Gamal; sherif@squ.edu.om
}

Received 8 August 2015; Revised 6 September 2015; Accepted 9 September 2015

Academic Editor: João M. L. Dos Reis

Copyright @ 2015 Sherif El-Gamal et al. This is an open access article distributed under the Creative Commons Attribution License, which permits unrestricted use, distribution, and reproduction in any medium, provided the original work is properly cited.

\begin{abstract}
Due to their high strength, corrosion resistance, and durability, fiber reinforced polymers (FRP) are very attractive for civil engineering applications. One of these applications is the strengthening of concrete columns with FRP sheets. The performance of this strengthening technique at elevated temperature is still questionable and needs more investigations. This research investigates the effects of exposure to high temperatures on the compressive strength of concrete cylinders wrapped with glass and carbon FRP sheets. Test specimens consisted of 30 unwrapped and 60 wrapped concrete cylinders. All specimens were exposed to temperatures of 100,200 , and $300^{\circ} \mathrm{C}$ for periods of 1,2 , and 3 hours. The compressive strengths of the unwrapped concrete cylinders were compared with their counterparts of the wrapped cylinders. For the unwrapped cylinders, test results showed that the elevated temperatures considered in this study had almost no effect on their compressive strength; however, the wrapped specimens were significantly affected, especially those wrapped with GFRP sheets. The compressive strength of the wrapped specimens decreased as the exposure period and the temperature level increased. After three hours of exposure to $300^{\circ} \mathrm{C}$, a maximum compressive strength loss of about $25.3 \%$ and $37.9 \%$, respectively, was recorded in the wrapped CFRP and GFRP specimens.
\end{abstract}

\section{Introduction}

Fibre reinforced polymers (FRPs) have been recognized as a reinforcing, strengthening, and repairing advanced material for civil engineering infrastructures worldwide [1-3]. They have been used as a replacement for conventional steel reinforcement in several new concrete structures such as bridges, parking garages, and concrete pavements [4-6]. One of the main applications of FRPs is the use of FRP jackets in building and bridge columns. Research initiatives around the world during the past two decades have documented the behaviour of externally bonded FRPs for strengthening reinforced concrete (RC) structures. In these applications, FRPs are bonded to the exterior of RC structures, typically using an epoxy resin saturant/adhesive, to provide additional tensile or confining reinforcement $[7,8]$. FRP jackets are most effective at confining members with circular cross sections [9-13]. The FRP system provides a circumferentially uniform confining pressure to the radial expansion of the compression member when the fibers are aligned transverse to the longitudinal axis of the member.

Sufficient research and implementations have been conducted for the development of various design codes and guidelines for the application of FRPs in conjunction with concrete structures. Numerous studies have shown that circumferential wraps of FRP on the exterior of reinforced concrete columns can significantly increase the strength and ductility of these members. Hence, FRP applications have been widespread in repair and restoration of reinforced concrete columns in existing bridges [14].

FRP sheets have been used for strengthening of columns, slabs, beams, and so forth. Some of the advantages of FRP sheets are that they can be applied easily and quickly, provide high resistance to the reinforced elements, and do not affect the shape of the structure. Although it was found that the behaviour of FRP-strengthened concrete structures at normal 
temperature is satisfactory, little information regarding the behaviour of FRP-strengthened concrete members at high temperatures is available [15].

The objective of this research was to investigate the effect of elevated temperatures on the performance of concrete cylinders confined with glass FRP (GFRP) and carbon FRP (CFRP) sheets. To achieve this objective, an experimental investigation including the construction and testing of 90 standard $100 \mathrm{~mm}$ diameter $\times 200 \mathrm{~mm}$ height concrete cylinders was made. Out of these specimens, 30 cylinders were unwrapped and the remaining 60 specimens were wrapped with one layer of GFRP or CFRP sheets. Some of the cylinders were exposed to room temperature, whereas other cylinders were exposed to heating regime of $100^{\circ} \mathrm{C}, 200^{\circ} \mathrm{C}$, and $300^{\circ} \mathrm{C}$ for a period of 1,2 , and 3 hours. After high temperature exposure, specimens were tested under uniaxial compression until failure.

\section{Literature Review}

In a review study by Hollaway [16], it was concluded that temperature is one of the most physical parameters that affects the original state of FRP material. It changes or resets the arrangement of the monomer and consequently affects the whole properties of FRPs. The measurements demonstrate one critical temperature value called glass transition temperature $\left(T_{g}\right) . T_{g}$ is the midpoint of two different critical phases. Polymers below $T_{g}$ are rigid and have both stiffness and strength, but above $T_{g}$, the polymers are viscous liquids and have much lower stiffness and strength. All physical properties of thermosetting polymers depend upon intermolecular cross-links and the temperature at which polymer will begin to soften $\left(T_{g}\right)$. The temperature at which this happens depends upon the chemical structure building of the polymer [16].

The behaviour of FRP confined concrete cylinders after exposure to different temperatures has been investigated by Al-Salloum et al. [14]. The research included two phases; the first phase included the construction of concrete prisms while the second phase included the construction of standard concrete cylinders. In the first phase, the concrete prisms were wrapped by one layer of GFRP and CFRP laminates for conducting pull-of strength tests. In the second phase, concrete cylinders were wrapped with one layer of CFRP or GFRP sheets. Some of the wrapped and unwrapped specimens were exposed to room temperature. The other concrete cylinders were exposed to heating regime of $100^{\circ} \mathrm{C}$ and $200^{\circ} \mathrm{C}$ for different periods. The reduction of strength capacity of specimens was noticed for wrapped carbon and glass FRP specimens after being exposed to heating of $100^{\circ} \mathrm{C}$ for 2 hours because of epoxy melting. This reduction was significantly experienced at a temperature of $200^{\circ} \mathrm{C}$.

Yaqub et al. $[17,18]$ studied the performance of postheated reinforced concrete square columns repaired with unidirectional FRPs. The test specimens were divided into three groups: unheated columns, postheated columns, and postheated columns wrapped with a single layer of unidirectional glass or carbon FRP jackets. The research investigated the stiffness, ductility, ultimate strain, and ultimate strength of all specimens.

The ultimate strength of unstrengthened square columns was reduced significantly after heating to $500^{\circ} \mathrm{C}$ due to burning of cement, which reduced its capacity. On the other hand, some improvements were noticed after wrapping the specimens with one layer of CFRP or GFRP sheets. This improvement was due to confining of concrete dilation by the FRP sheet. However, the strength of postheated square columns could be restored to some extent but below the original level of undamaged concrete. This limitation of improvement was due to cross section of the columns where the distribution of lateral confining pressure of the GFRP or CFRP jackets varies from a maximum at the corners to a minimum between the corners due to arching action. The research recommended increasing the number of GFRP or CFRP layers and increasing corner radius to enhance the capacity of the columns.

Trapko [19] studied the effect of high temperature on the performance of CFRP and FRCM (Fiber Reinforced Cementitious Matrix) confined concrete elements. Concrete cylinders were wrapped with CFRP sheets and FRCM mesh and exposed to temperature of $40^{\circ} \mathrm{C}, 60^{\circ} \mathrm{C}$, and $80^{\circ} \mathrm{C}$ over a period of 24 hours. The testing program was carried out on 24 concrete cylinders: 6 were unwrapped specimens, 9 were wrapped with two layers of CFRP, and the remaining 9 specimens were wrapped with two layers of FRCM mesh. The CFRP wrapped cylinders failed through a sudden rapture of fiber sheet. Failure of FRCM confined elements was initiated by debonding of mesh at the external pleat. In case of CFRP confined elements, higher temperature significantly reduced the compressive strength of the confined specimens. Load dropped by about $10 \%$ per each $20^{\circ} \mathrm{C}$ on average. For the FRCM confined specimens, temperature did not have that significant effect. Changes ranged between only 5 and $10 \%$. Trapko developed an empirical equation to calculate the compressive strength of confined concrete cylinders. However, there was a large difference between experimental and empirical results. From literature, it can be concluded that more research is required to investigate the performance of FRP wrapped concrete columns after exposure to elevated temperatures.

\section{Experimental Testing Program}

3.1. Test Specimens. The experimental work in this study included the construction and testing of 90 concrete cylinders of $100 \mathrm{~mm}$ diameter $\times 200 \mathrm{~mm}$ height. The specimens consisted of 30 unwrapped cylinders, 30 cylinders wrapped with one layer of CFRP sheets, and 30 cylinders wrapped with one layer of GFRP sheets. All specimens were exposed to $100^{\circ} \mathrm{C}$, $200^{\circ} \mathrm{C}$, and $300^{\circ} \mathrm{C}$ for a period of 1,2 , and 3 hours. After high temperature exposure, specimens were tested under uniaxial compression until failure according to ASTM C39 test method [20].

The test results included the ultimate capacity and failure mode. Table 1 summarizes the schedule of test specimens 
TABLE 1: Schedule of test specimens.

\begin{tabular}{|c|c|c|c|c|}
\hline Time of exposure (h) & Temperature $\left({ }^{\circ} \mathrm{C}\right)$ & Unwrapped specimens & Wrapped with CFRP & Wrapped with GFRP \\
\hline- & Room & 3 & 3 & 3 \\
\hline \multirow{3}{*}{1} & 100 & 3 & 3 & 3 \\
\hline & 200 & 3 & 3 & 3 \\
\hline & 300 & 3 & 3 & 3 \\
\hline \multirow{3}{*}{2} & 100 & 3 & 3 & 3 \\
\hline & 200 & 3 & 3 & 3 \\
\hline & 300 & 3 & 3 & 3 \\
\hline \multirow{3}{*}{3} & 100 & 3 & 3 & 3 \\
\hline & 200 & 3 & 3 & 3 \\
\hline & 300 & 3 & 3 & 3 \\
\hline \multirow[t]{2}{*}{ Total number of specimens } & & 30 & 30 & 30 \\
\hline & & & 90 & \\
\hline
\end{tabular}

TABLE 2: Required batch quantities for the 90 cylinders (in $\mathrm{kg}$ ).

\begin{tabular}{lcccc}
\hline & $\begin{array}{c}\text { Aggregate } \\
10 \mathrm{~mm}\end{array}$ & Fine & Cement & Water \\
\hline 105.36 & 69.32 & 126.5 & 50.36 & 33.87 \\
\hline
\end{tabular}

where a replicate of three specimens was used for each condition.

\subsection{Used Materials}

3.2.1. Concrete. Normal concrete with a target compressive strength of $30 \mathrm{MPa}$ was prepared in the laboratory for concrete casting. The procedure of concrete mixing was carried out according to ASTM standards. Table 2 shows the mix quantities required for casting the 90 cylinders. Compressive and tensile strength tests were carried out using standard concrete cylinders and cubes that were cast and cured according to [21]. Test results show that the measured concrete compressive and tensile strengths were 21.5 and $2.35 \mathrm{MPa}$, respectively.

3.2.2. FRP Sheets and Resin. Uniaxial CFRP sheets and biaxial GFRP sheets were used for confining the concrete cylinders. The ultimate load of the CFRP sheets as given by the manufacturer is $350 \mathrm{kN} / \mathrm{m}$ and $180 \mathrm{kN} / \mathrm{m}$ width, respectively. Detailed mechanical properties of the FRP sheets used can be found in [22]. Figure 1 shows the CFRP sheet used. An epoxy resin was used for bonding the FRP sheets to concrete. According to manufacturers, the epoxy resin had a compressive strength greater than $60 \mathrm{MPa}$, bending strength greater than $50 \mathrm{MPa}$, and bond strength greater than $3 \mathrm{MPa}$. Figure 2 shows epoxy resin used for bonding FRP sheets. More details about the mechanical properties of the epoxy resin used can be found in [23].

3.3. Casting and Curing of Specimens. Ninety PVC pipes with an inside diameter of $100 \mathrm{~mm}$ and $200 \mathrm{~mm}$ height were used

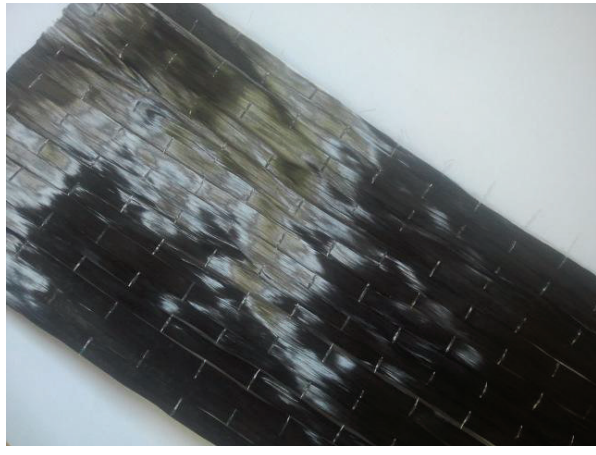

FIGURE 1: CFRP sheet sample.

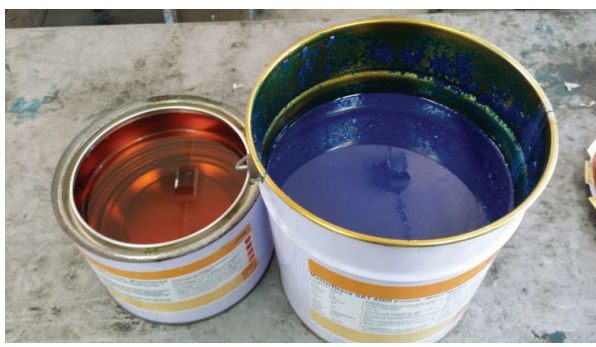

FIGURE 2: Epoxy resin used for bonding of FRP sheets.

for concrete casting. Before casting, oil was added to the inner sides of the pipes to facilitate removing the concrete cylinder after casting. The pipes were put inside a vibration machine to compact concrete as shown in Figure 3. After concrete casting, the specimens were kept in the lab for one day. Then, the concrete specimens were removed from the moulds and were submerged in water for 28 days for curing as shown in Figure 4.

3.4. Application of FRP Sheets. The application of the FRP sheets was conducted according to ISIS manuals and ACI440$2 \mathrm{R}$ guidelines $[24,25]$. Before confining the concrete with 


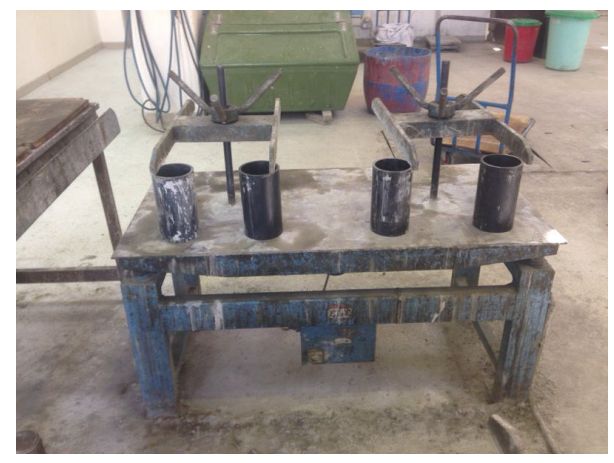

FIGURE 3: Specimens on the vibration machine before casting.

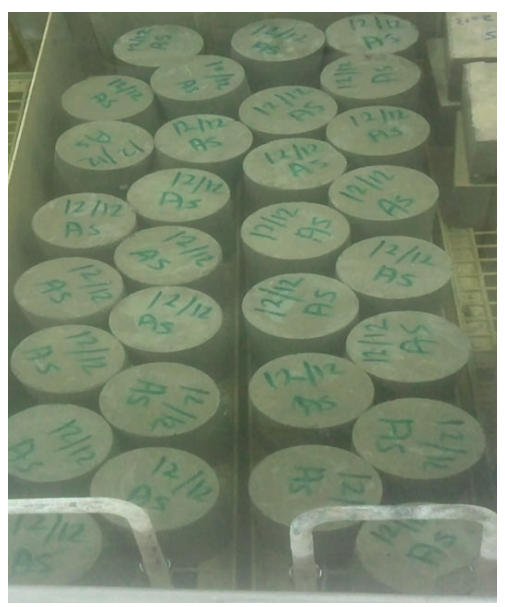

FIGURE 4: Curing of concrete cylinders.

FRP sheets, the surface of the concrete specimens was polished to remove voids and deformities on it. The twocomponent epoxy system, consisting of resin and hardener, was thoroughly hand-mixed for at least 5 minutes before use. The FRP sheets were then applied directly onto the surface of the specimens providing unidirectional lateral confinement in the hoop direction. Figure 5 shows the steps of confining cylinder by the GFRP sheets.

After applying the FRP sheet, all specimens were stored at room temperature for at least 7 days to ensure enough time for curing of epoxy. Before testing, all specimens were exposed to heating regimes of $100^{\circ} \mathrm{C}, 200^{\circ} \mathrm{C}$, and $300^{\circ} \mathrm{C}$ for a period of 1,2 , and 3 hours. After heating, the specimens were taken out from the oven and left to cool in the lab temperature before testing. This procedure was chosen to investigate any permanent deterioration caused by elevated temperatures in the fibres or in the resin. Another study is being carried out by the authors to test specimens directly after heating and its results will be included in another paper.

\section{Test Results and Discussion}

Tables 3-5 summarize the test results of unconfined and confined test specimens. It should be noted that the values
TABLE 3: Test results of the unconfined specimens.

\begin{tabular}{|c|c|c|c|}
\hline \multicolumn{4}{|c|}{ Average compressive strength $(\mathrm{MPa})$} \\
\hline \multirow{2}{*}{ Temperature } & \multicolumn{3}{|c|}{ Exposure time $(\mathrm{h})$} \\
\hline & $1 \mathrm{~h}$ & $2 \mathrm{~h}$ & $3 \mathrm{~h}$ \\
\hline $100^{\circ} \mathrm{C}$ & $21.72 \pm 0.8$ & $20.41 \pm 0.6$ & $18.64 \pm 0.5$ \\
\hline $200^{\circ} \mathrm{C}$ & $23.03 \pm 1.4$ & $19.44 \pm 1.2$ & $18.62 \pm 1.3$ \\
\hline $300^{\circ} \mathrm{C}$ & $20.19 \pm 0.5$ & $18.90 \pm 1.3$ & $18.57 \pm 0.9$ \\
\hline Room & & $21.44 \pm 0.7$ & \\
\hline
\end{tabular}

TABLE 4: Test results of CFRP confined specimens.

\begin{tabular}{lccc}
\hline & \multicolumn{3}{c}{ Average compressive strength (MPa) } \\
Temperature & $1 \mathrm{~h}$ & $2 \mathrm{~h}$ & $3 \mathrm{~h}$ \\
\hline $100^{\circ} \mathrm{C}$ & $56.1 \pm 1.1$ & $57.3 \pm 0.9$ & $54.7 \pm 0.4$ \\
$200^{\circ} \mathrm{C}$ & $56.9 \pm 1.3$ & $56.4 \pm 1.8$ & $52.6 \pm 0.7$ \\
$300^{\circ} \mathrm{C}$ & $55.4 \pm 0.6$ & $53.5 \pm 1.5$ & $41.0 \pm 1.3$ \\
Room & & $54.9 \pm 1.4$ & \\
\hline
\end{tabular}

TABLE 5: Test results of GFRP confined specimens.

\begin{tabular}{lccc}
\hline & \multicolumn{3}{c}{ Average compressive strength (MPa) } \\
Temperature & $1 \mathrm{~h}$ & $2 \mathrm{~h}$ & $3 \mathrm{~h}$ \\
\hline $100^{\circ} \mathrm{C}$ & $30.61 \pm 0.7$ & $30.01 \pm 0.5$ & $27.82 \pm 1.1$ \\
$200^{\circ} \mathrm{C}$ & $27.14 \pm 1.4$ & $27.14 \pm 0.8$ & $23.07 \pm 0.5$ \\
$300^{\circ} \mathrm{C}$ & $22.48 \pm 0.4$ & $22.48 \pm 1.2$ & $20.96 \pm 0.8$ \\
Room & & $33.77 \pm 1.2$ \\
\hline
\end{tabular}

of compressive strength presented in Tables 3-5 are the average of three specimens. The test results of all specimens were consistent. The standard deviation ranged between 0.5 and $1.4 \mathrm{MPa}$ for unconfined specimens with coefficients of variations between 2.7 and $6.1 \%$. For the CFRP confined specimens, the standard deviations ranged between 0.4 and $1.8 \mathrm{MPa}$ with coefficient of variation between about 1 and $3.2 \%$. Similar observations were recorded in the GFRP confined specimens where the standard deviations ranged between 0.4 and $1.4 \mathrm{MPa}$ with coefficients of variations between 1.8 and $5.2 \%$.

4.1. Unconfined Specimens. Before testing, the unconfined specimens were exposed to room temperature and the heating regimes explained earlier. Thereafter, the specimens were tested in uniaxial compression. The performance of cylinders under axial load was found to be consistent. Table 3 reports the compressive strength of the unconfined specimens. The failure mode was characterized by shearing and splitting of concrete, as shown in Figure 6. It can be noticed that elevated temperatures considered in this study had very small effect on the compressive strength of the unconfined specimens.

4.2. CFRP Confined Specimens. Table 4 shows the compressive strength test results of the CFRP wrapped specimens 

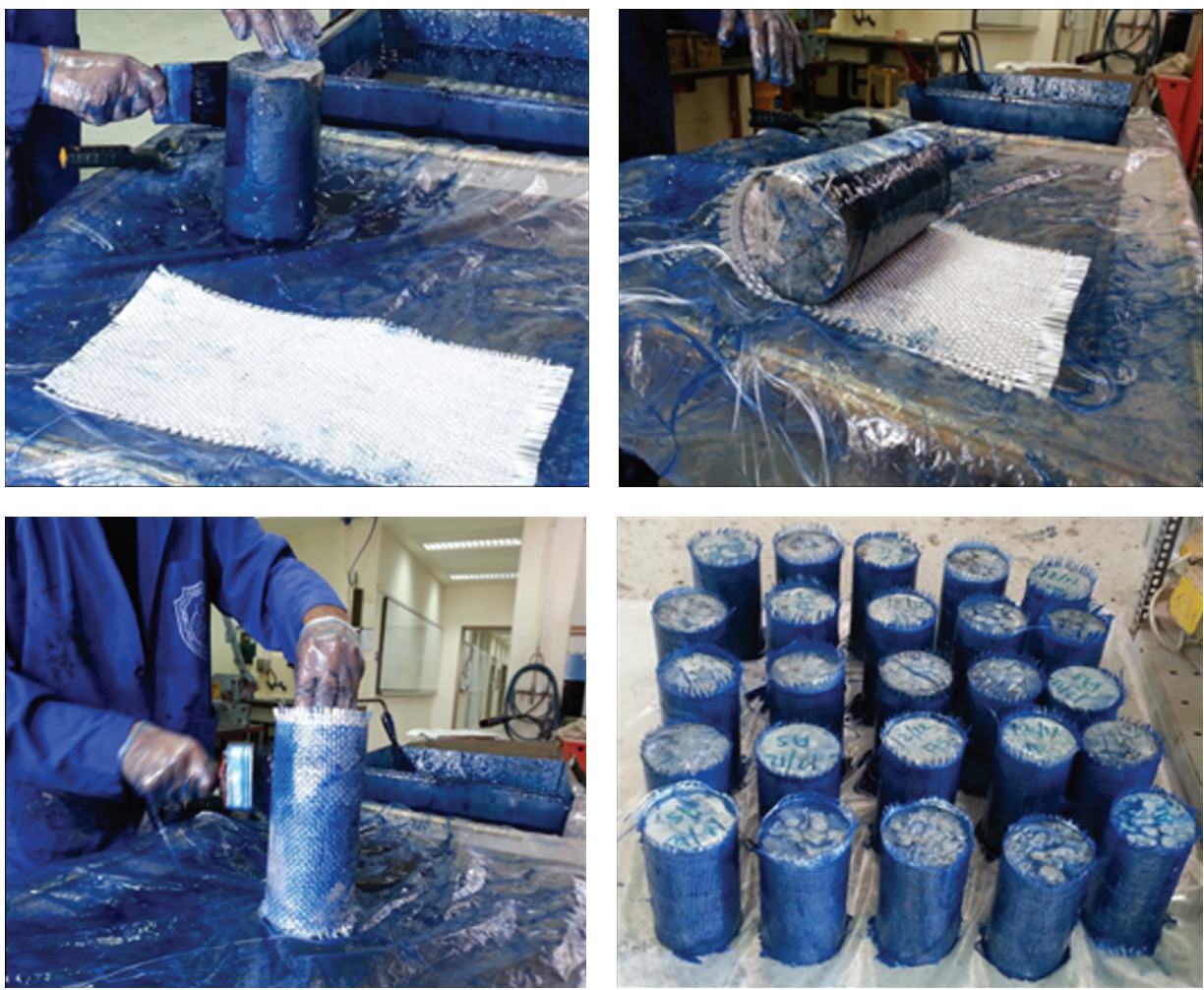

FIGURE 5: Steps of confining process.

after exposure to room temperature and heating regimes. It can be noticed that wrapping the concrete cylinders with CFRP sheets increased the compressive strength compared to the unconfined specimens. This increase ranged between 120 and $190 \%$. All confined specimens show higher compressive strengths compared to unconfined specimens regardless of exposure period or temperature level. Table 4 also shows that one and two hours of exposure to $100^{\circ} \mathrm{C}, 200^{\circ} \mathrm{C}$, and $300^{\circ} \mathrm{C}$ did not show a significant effect of the compressive strength compared to the confined specimens at room temperature. However, a significant decrease in the compressive strength (about 25\%) was recorded after 3 hours of exposure to $300^{\circ} \mathrm{C}$ compared to the confined specimen at room temperature.

All the CFRP confined specimens failed by CFRP rupture in an explosive pattern with a huge energy dissipation regardless of temperature level or exposure period. Figure 7 shows photos of two CFRP wrapped specimens after failure.

4.3. GFRP Confined Specimens. Table 5 presents the compressive test results of the GFRP confined specimens. It can be noticed that wrapping the concrete cylinders with GFRP sheets slightly increased the compressive strength compared to the unconfined specimens (see Table 3 ). This increase ranged between only $11 \%$ after exposure to $300^{\circ} \mathrm{C}$ and $57 \%$ at room temperature. Table 5 also shows that the temperature level had a significant effect on the GFRP confined specimens. All specimens exposed to elevated temperatures showed lower compressive strength compared to the wrapped specimens in room temperature. Increasing the temperature level significantly affected the compressive strength of the wrapped specimens as shown in Figure 8. The exposure period, however, had less influence on the compressive strength compared to the effect of temperature level.

All the GFRP confined specimens also failed by GFRP rupture regardless of temperature level or exposure period. Figure 9 shows typical failures of the GFRP wrapped specimens.

Figure 9 shows a colour change in the GFRP sheets after exposure to $200^{\circ} \mathrm{C}$ and $300^{\circ} \mathrm{C}$. This is a sign of a permanent deterioration in the GFRP sheets, which explains the decrease in the compressive strength of the GFRP wrapped specimens after being exposed to elevated temperatures. This indicates that elevated temperatures had more harmful effect on the GFRP sheets than CFRP sheets.

4.4. Comparison of Test Results. Figure 10 shows the average compressive strength of all test specimens after exposure to different temperatures and exposure periods. The figure shows that the CFRP confined specimens had the maximum compressive strength followed by the GFRP confined specimens and then by the unconfined specimens.

For all test specimens, the exposure period had a minor effect on the compressive strength except for the CFRP confined specimen at $300^{\circ} \mathrm{C}$ where increasing the exposure period from 2 to 3 hours resulted in a significant decrease in the compressive strength. It can be also noticed that 

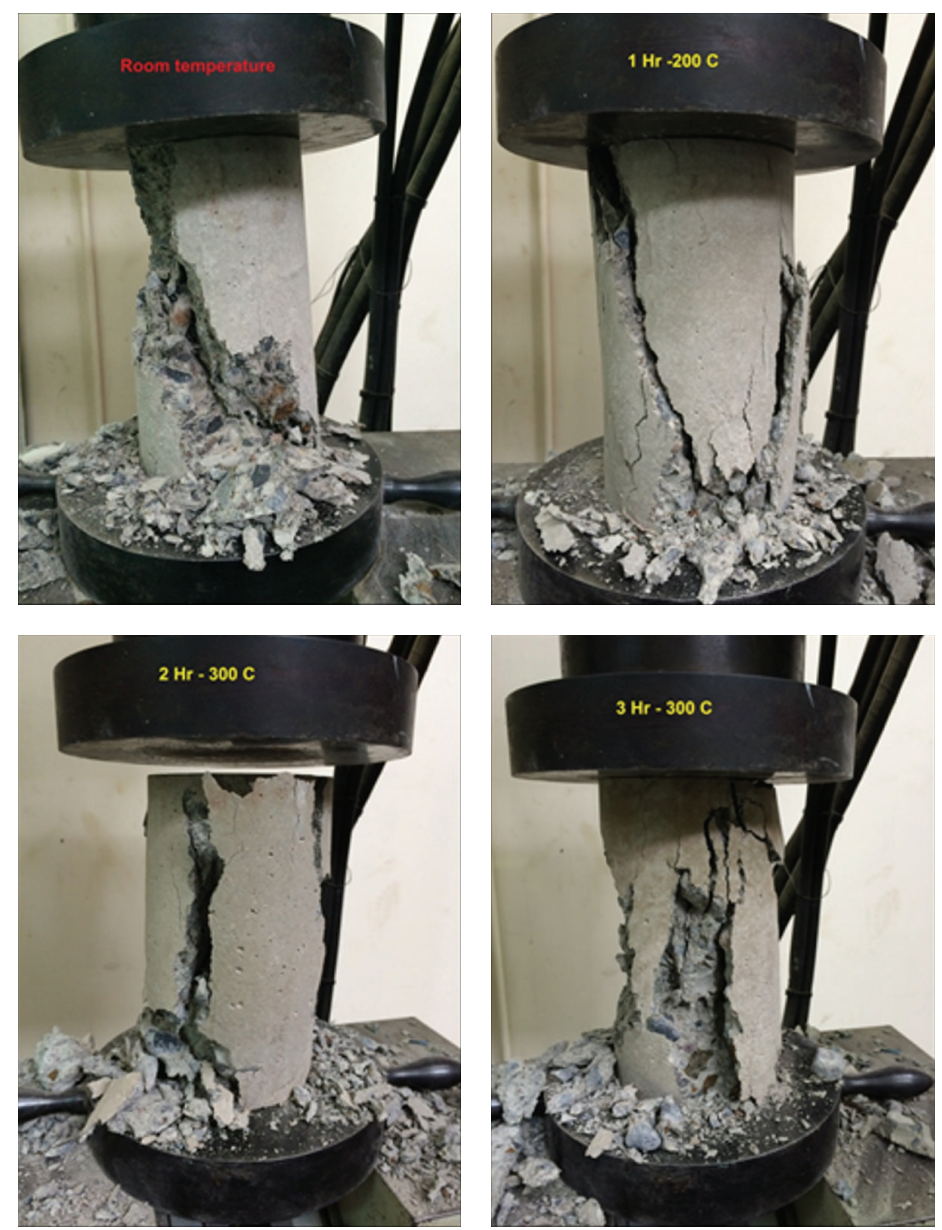

FIGURE 6: Failure of the unconfined specimens.
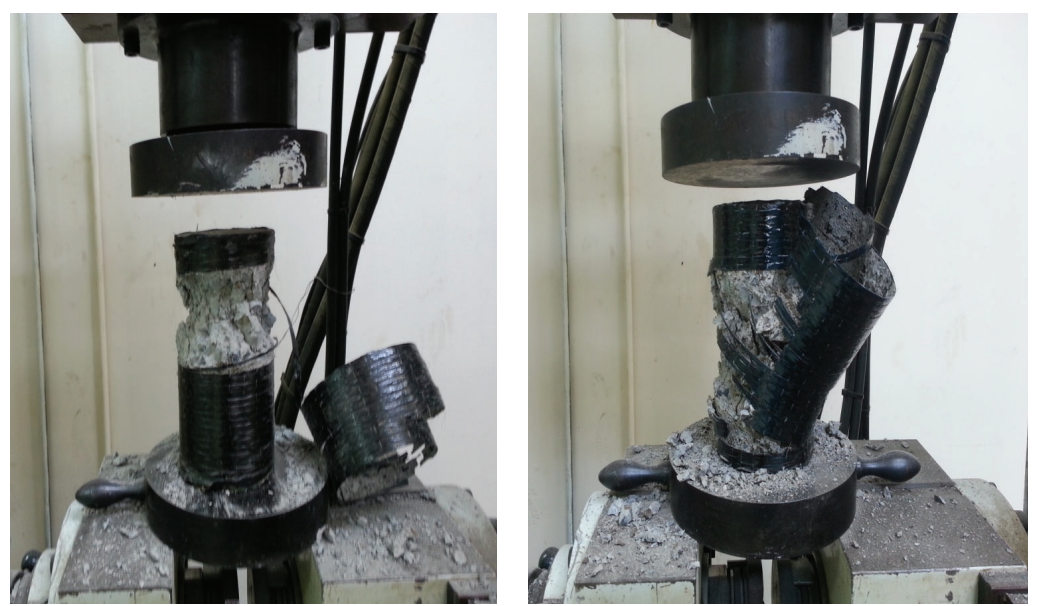

FIGURE 7: Failure of CFRP wrapped specimens.

increasing the temperature level had greater effect on the compressive strength than exposure period especially for the GFRP confined specimens.

Figure 11 shows the compressive strength loss of heated test specimens compared to the corresponding specimen at room temperature. For the unconfined specimens, it can be noticed that the exposure period and temperature had insignificant effect on the compressive strength. A maximum strength loss of about $13.4 \%$ compared to specimen in room temperature was recorded after 3 hours of exposure to $300^{\circ} \mathrm{C}$. A similar observation can be noticed for the CFRP confined specimens. Except for the specimens exposed to $300^{\circ} \mathrm{C}$ for 


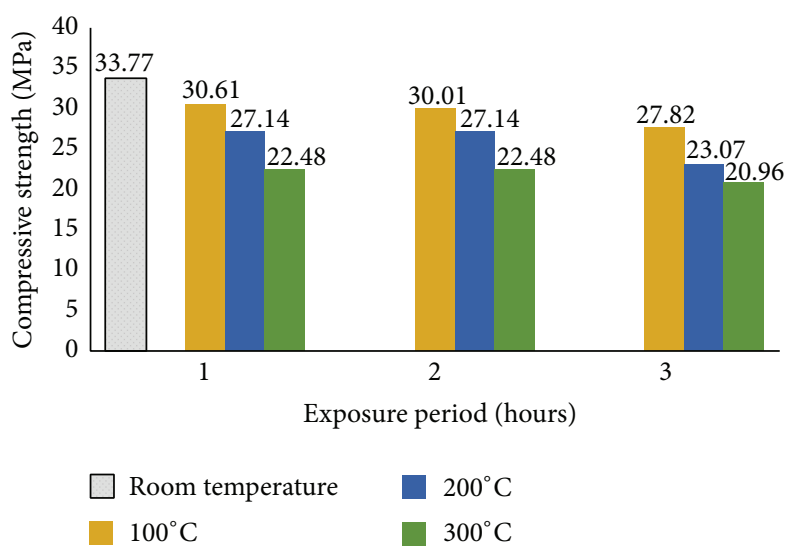

FIGURE 8: Average compressive strength of GFRP confined specimens after exposure to different temperatures.
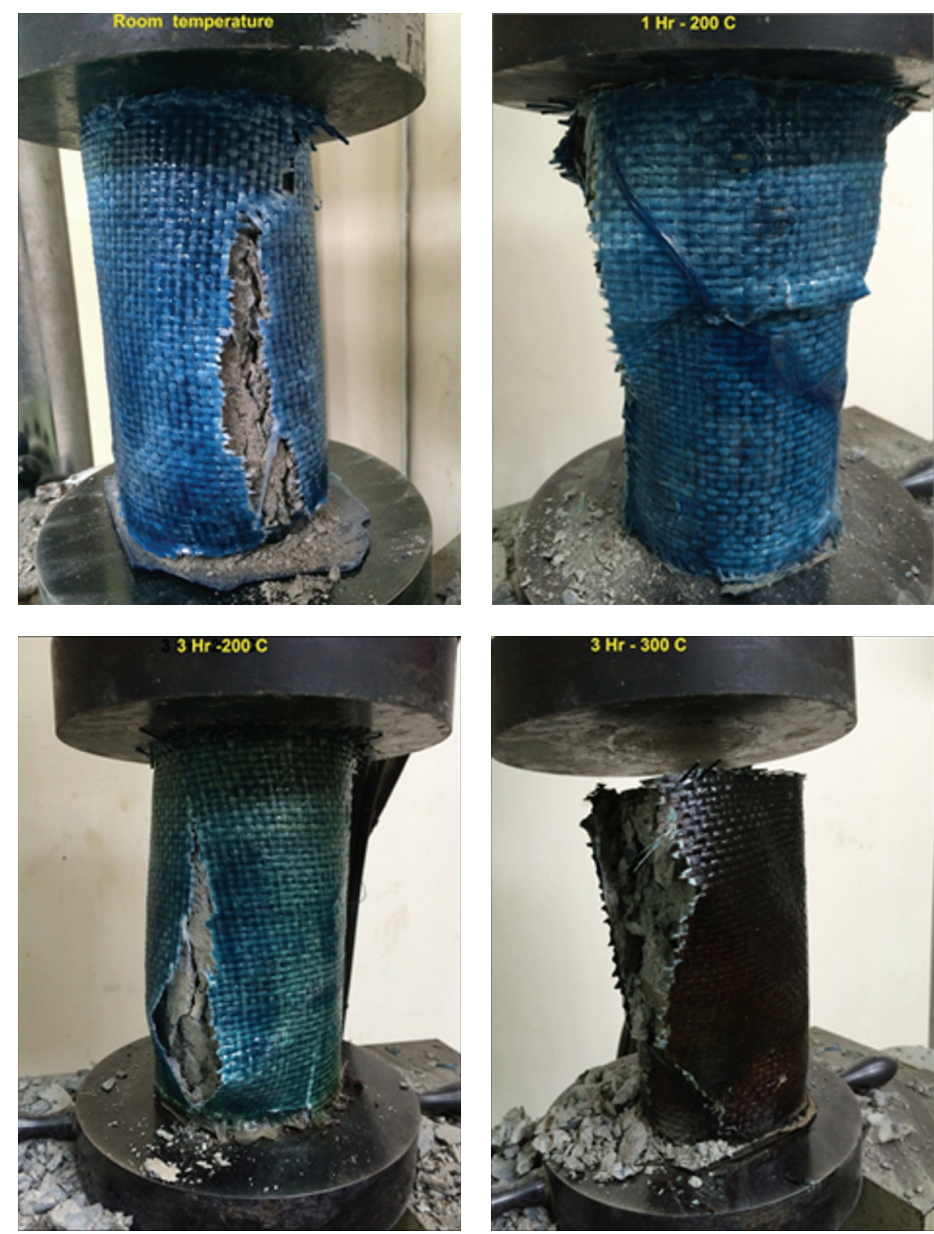

FIGURE 9: Failure of GFRP wrapped specimens.

3 hours that show a strength loss of about $25 \%$, all other specimens, CFRP confined specimens, almost did not show any strength loss compared to the CFRP confined specimen at room temperature. For the GFRP confined specimens, Figure 11 shows that significant compressive strength losses were recorded. The strength losses increased as the temperature level or exposure period increased. The strength losses ranged between 9.4 and 17.6 at $100^{\circ} \mathrm{C}, 19.6$ and 31.7 at $200^{\circ} \mathrm{C}$, and 33.4 and 37.9 at $300^{\circ} \mathrm{C}$.

\section{Conclusions}

This study aimed to investigate the compressive strength of carbon and glass FRP confined concrete cylinders after 

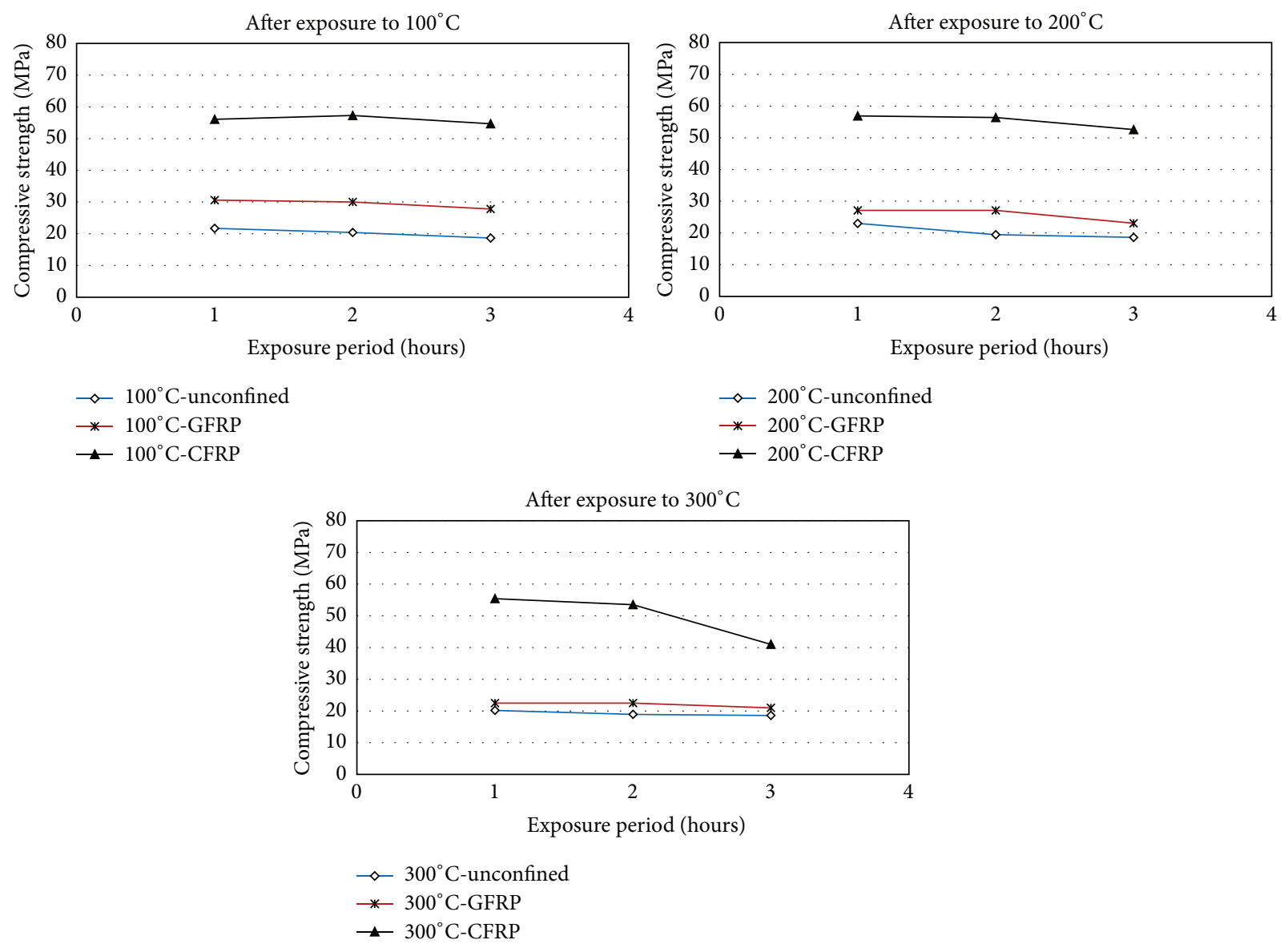

Figure 10: Comparison of test results.

exposure to elevated temperatures. The experimental program consisted of 90 concrete cylinders: 30 unwrapped, 30 wrapped with GFRP sheets, and 30 wrapped with CFRP sheets. All specimens were exposed to $100^{\circ} \mathrm{C}, 200^{\circ} \mathrm{C}$, and $300^{\circ} \mathrm{C}$ for period of 1,2 , or 3 hours. The compressive strength of wrapped concrete cylinder with FRP sheets was compared with the unwrapped concrete cylinders under the same conditions. Based on test results, the following conclusions can be drawn:

(i) All CFRP and GFRP wrapped specimens showed higher compressive strengths compared to unwrapped specimens. This increase ranged between 120 and $190 \%$ and 11 and 57\% for CFRP and GFRP wrapped specimens, respectively. This indicates that the CFRP sheets were more effective in increasing the capacity of concrete cylinders.

(ii) All wrapped specimens failed by rupture of the FRP sheets.

(iii) The elevated temperatures considered in this study had a minor effect on the compressive strength of the unwrapped specimens. A maximum strength loss of about $13 \%$ was recorded after exposure to $300^{\circ} \mathrm{C}$.

(iv) For the CFRP wrapped specimens, the elevated temperatures considered in this study almost did not affect the compressive strength except for the specimens exposed to $300^{\circ} \mathrm{C}$ for 3 hours that showed a strength loss of about $25 \%$ compared to the CFRP wrapped specimens at room temperature.

(v) For the GFRP wrapped specimens, significant compressive strength losses were recorded after exposure to elevated temperatures. The strength losses increased as the temperature level or exposure period increased. A maximum compressive strength loss of $37.9 \%$ was recorded after exposure to $300^{\circ} \mathrm{C}$ for 3 hours.

(vi) The elevated temperatures considered in this study affected more the GFRP sheets than CFRP. This was recorded from the change in the colour of the sheets and high compressive strength losses recorded in those specimens. 

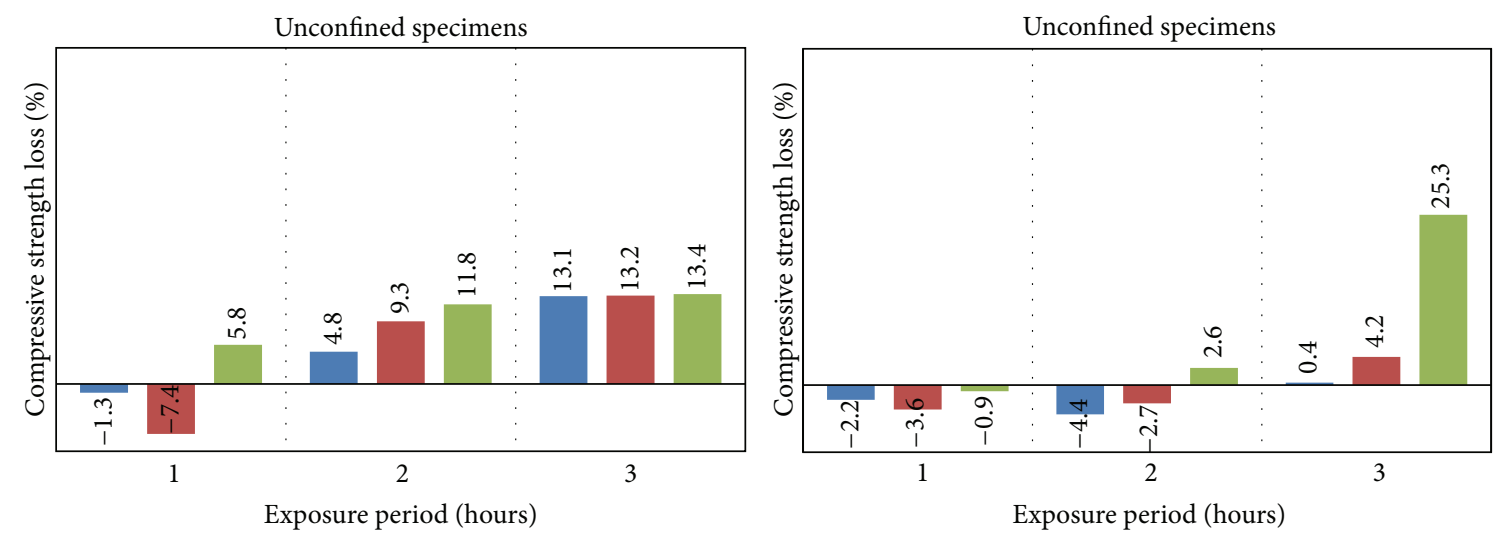

$100^{\circ} \mathrm{C}$-unconfined

$200^{\circ} \mathrm{C}$-unconfined

$100^{\circ} \mathrm{C}$-CFRP

$300^{\circ} \mathrm{C}$-unconfined

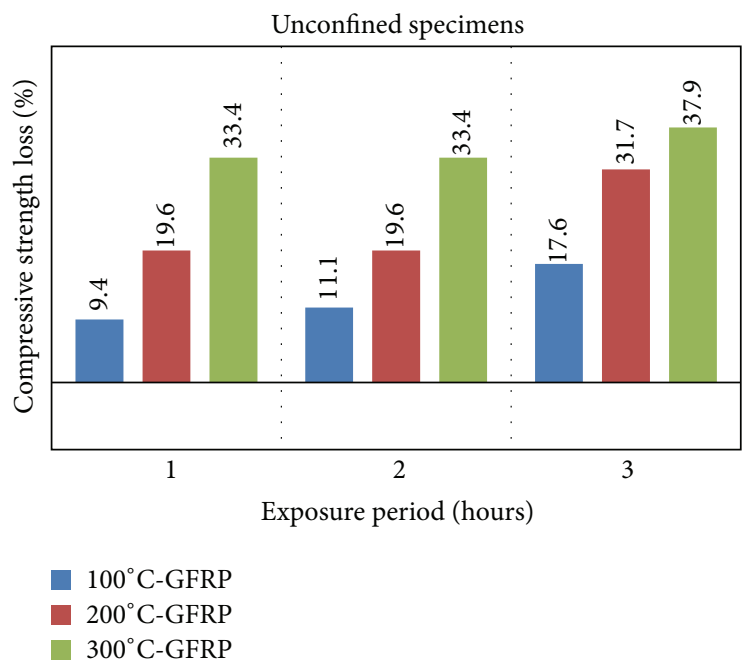

FIGURE 11: Compressive strength loss.

\section{Conflict of Interests}

The authors declare that there is no conflict of interests regarding the publication of this paper.

\section{Acknowledgments}

The authors would like to acknowledge Sultan Qaboos University and the Civil and Architectural Engineering Department for their support to conduct this research project. Thanks are also extended to the technicians at the structural laboratory of the Civil and Architectural Engineering Department for their help.

\section{References}

[1] S. E. El-Gamal, Behaviour of restrained concrete bridge deck slabs reinforced with FRP reinforcing bars under concentrated loads [Ph.D. thesis], Université de Sherbrooke, Québec, Canada, 2005.

[2] S. E. El-Gamal, Y. Al-Salloum, S. Alsayed, and M. Aqel, "Performance of near surface mounted glass fiber reinforced polymer bars in concrete," Journal of Reinforced Plastics and Composites, vol. 31, no. 22, pp. 1501-1515, 2012.

[3] Y. A. Al-Salloum, S. E. El-Gamal, T. H. Almusallam, S. H. Alsayed, and M. Aqel, "Effect of harsh environmental conditions on the tensile properties of GFRP bars," Composites Part B: Engineering, vol. 45, no. 1, pp. 835-844, 2013.

[4] B. Benmokrane, E. El-Salakawy, A. El-Ragaby, and S. El-Gamal, "Performance evaluation of innovative concrete bridge deck slabs reinforced with fibre-reinforced-polymer bars," Canadian Journal of Civil Engineering, vol. 34, no. 3, pp. 298-310, 2007.

[5] M. Eisa, S. E. El-Gamal, E. El-Salakawy, and B. Benmokrane, "Design and construction of first GFRP-CRC200P slabs implemented on highway 40 east (Montreal)," in Proceedings of the 37th Annual Conference of the Canadian Society for Civil Engineering, pp. 1-8, Québec City, Canada, 2008.

[6] S. E. El-Gamal, B. Benmokrane, E. El-Salakawy, P. Cousin, and A. Wiseman, "Durability and structural performance of carbon fibre reinforced polymer-reinforced concrete parking garage slabs," Canadian Journal of Civil Engineering, vol. 36, no. 4, pp. 617-627, 2009.

[7] ACI Committee 440, 440.2R-08 Guide for the Design and Construction of Externally Bonded FRP Systems for Strengthening 
Concrete Structures, ACI Committee, Farmington Hills, Mich, USA, 2008.

[8] S. E. El-Gamal, A. Al-Nuaimi, A. Al-Saidy, and A. Al-Lawati, "Flexural strengthening of RC beams using near surface mounted fibre reinforced polymers," in Proceedings of the 5th Brunei International Conference on Engineering and Technology (BICET '14), pp. 1-7, Institut Teknologi Brunei, Darussalam, Bandar Seri Begawan, Brunei, November 2014.

[9] M. Demers and K. W. Neale, "Confinement of reinforced concrete columns with fibre-reinforced composite sheets-an experimental study," Canadian Journal of Civil Engineering, vol. 26, no. 2, pp. 226-241, 1999.

[10] K. A. Harries and S. A. Carey, "Shape and 'gap' effects on the behavior of variably confined concrete," Cement and Concrete Research, vol. 33, no. 6, pp. 881-890, 2003.

[11] M. N. Youssef, Stress strain model for concrete confined by FRP composites [Ph.D. thesis], University of California, Irvine, Irvine, Calif, USA, 2003.

[12] S. Matthys, H. Toutanji, K. Audenaert, and L. Taerwe, "Axial load behavior of large-scale columns confined with fiberreinforced polymer composites," ACI Structural Journal, vol. 102, no. 2, pp. 258-267, 2005.

[13] S. Rocca, N. Galati, and A. Nanni, "Experimental evaluation of FRP strengthening of large-size reinforced concrete columns," Report UTC-142, University of Missouri-Rolla, Rolla, Mo, USA, 2006.

[14] Y. A. Al-Salloum, H. M. Elsanadedy, and A. A. Abadel, "Behavior of FRP-confined concrete after high temperature exposure," Construction and Building Materials, vol. 25, no. 2, pp. 838-850, 2011.

[15] S. E. El-Gamal, "Bond strength of glass fiber-reinforced polymer bars in concrete after exposure to elevated temperatures," Journal of Reinforced Plastics and Composites, vol. 33, no. 23, pp. 2151-2163, 2014.

[16] L. C. Hollaway, "A review of the present and future utilisation of FRP composites in the civil infrastructure with reference to their important in-service properties," Construction and Building Materials, vol. 24, no. 12, pp. 2419-2445, 2010.

[17] M. Yaqub, C. G. Bailey, and P. Nedwell, "Axial capacity of postheated square columns wrapped with FRP composites," Cement \& Concrete Composites, vol. 33, no. 6, pp. 694-701, 2011.

[18] M. Yaqub and C. G. Bailey, "Cross sectional shape effects on the performance of post-heated reinforced concrete columns wrapped with FRP composites," Composite Structures, vol. 93, no. 3, pp. 1103-1117, 2011.

[19] T. Trapko, "The effect of high temperature on the performance of CFRP and FRCM confined concrete elements," Composites Part B: Engineering, vol. 54, no. 1, pp. 138-145, 2013.

[20] ASTM International, "Standard test method for compressive strength of cylindrical concrete specimens," ASTM C39, ASTM International, West Conshohocken, Pa, USA, 2015, http://www.astm.org/.

[21] British Standard BS 1881-111, Method of Normal Curing of Test Specimens, vol. 111, British Standards Institution, 1983.

[22] SikaWrap-230, http:/gcc.sika.com/en/struct-bond-strength-redirect/sika-structural-strengthening-solutions/02a013/02a013sa06 .html.

[23] http://www.basf-cc.com.sg/en/products/ConcreteRepairandProtectionSystems/MBrace/MBraceSaturant/Pages/default.aspx.

[24] ISIS Design Manual, Strengthening Reinforced Concrete Structures with Externally Bonded Fibre Reinforced Polymers,
The Canadian Network of Centers of Excellence on Intelligent Sensing for Innovative Structures, ISIS Canada, University of Winnipeg, Manitoba, Canada, 2001.

[25] ACI 440.2R-08, Guide for the Design and Construction of Externally Bonded FRP Systems for Strengthening Concrete Strucutres, American Concrete Institute, Farmington Hills, Mich, USA, 2008. 

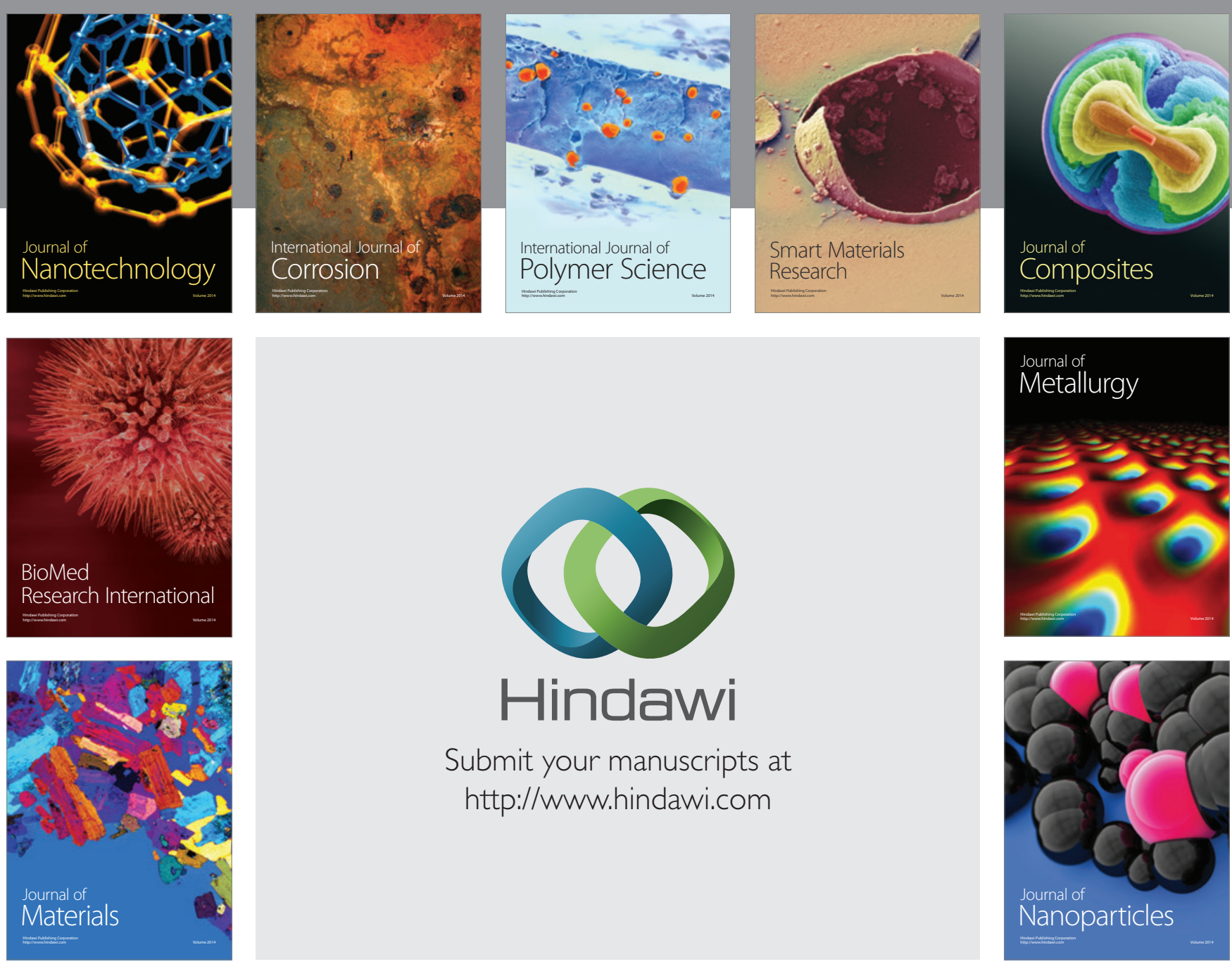

Submit your manuscripts at http://www.hindawi.com
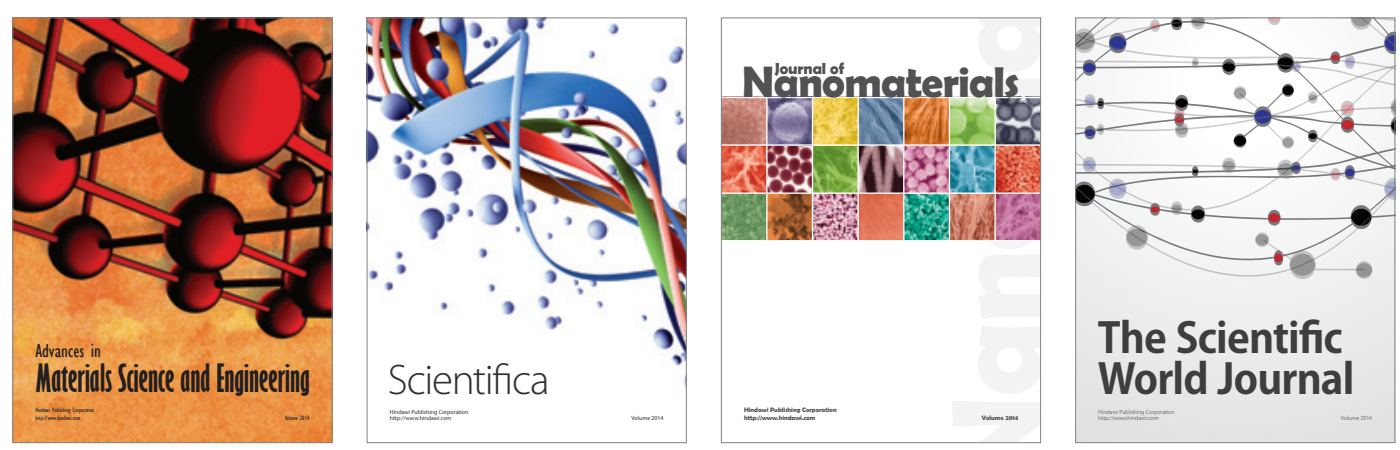

\section{The Scientific World Journal}
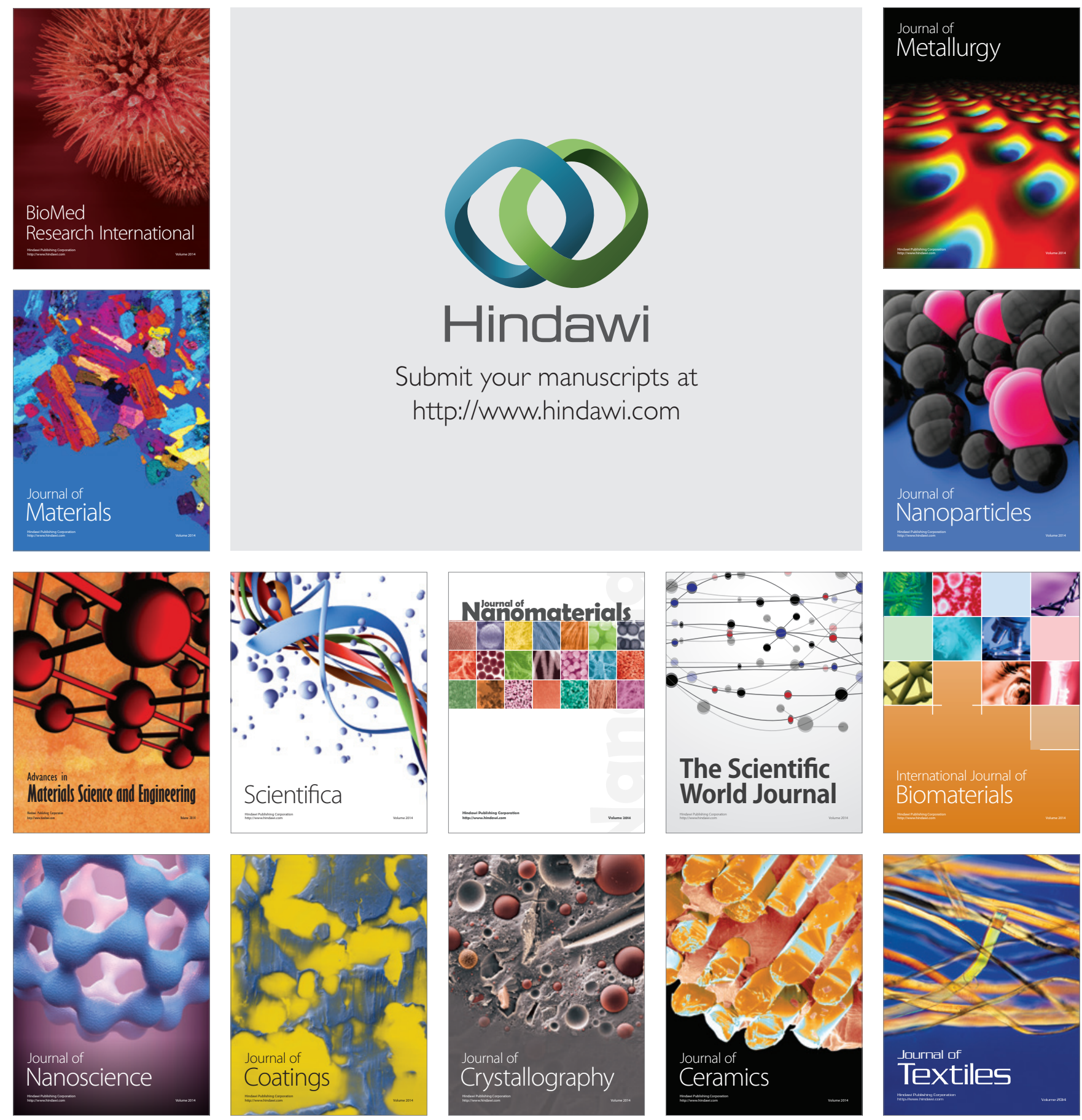